\title{
Mateusz Chrzanowski
}

Maria Curie-Skłodowska University in Lublin, Poland

ORCID: 0000-0002-4099-0980

m.chrzanowski@umcs.pl

\section{Public Hearing as a Part of the Legislative Procedure in the Senate}

\author{
Wysłuchanie publiczne jako element procedury \\ ustawodawczej w Senacie
}

\begin{abstract}
The article presents issues relating to public hearing as a social instrument influencing the legislative procedure in the Senate. This institution is in line with the constitutional assumptions relating to the principles of a democratic state ruled by law, national sovereignty, social dialogue and the right to be informed about the activities of public authorities. The conducted research begins with an analysis of the legal regulations concerning public hearing. Practice shows that, unfortunately, its potential is not properly used, because this tool of social participation is used extremely rarely. The further part of the article presents the elements of the law-making process that require changes. These changes could contribute to the improvement of its effectiveness. In particular, modifications should be implemented in the institutional sphere, within the framework of creating transparent rules of cooperation between participants in the law-making process.
\end{abstract}

Keywords: public hearing; Senate; legislative procedure; social participation; Poland

CORRESPONDENCE ADDRESS: Mateusz Chrzanowski, PhD, Assistant Professor, Maria Curie-Skłodowska University (Lublin), Faculty of Law and Administration, Institute of Law, Plac Marii Curie-Skłodowskiej 5, 20-031 Lublin, Poland. 


\section{INTRODUCTION}

The need to increase the direct participation of individuals and social groups in the constitutional mechanisms of exercising power has been raised more and more often recently. ${ }^{1}$ It is particularly important in the field of law-making by state bodies. The view should be shared that one of the key dilemmas related to law-making was and still is the problem related to determining the optimization of the law-making mode. ${ }^{2}$ The institutions of participatory democracy, which rely on expressing the will regarding public issues and serve as legislative inspiration, ${ }^{3}$ should certainly have an impact in this respect. It is worth emphasizing that these institutions are a manifestation of the realization of the idea of the nation's sovereignty, they strengthen the democratic character of the state's political system, and at the same time do not collide with the instruments of indirect democracy, as they complement it. ${ }^{4}$ Moreover, they perform a specific control function of the authorities, which is a testimony to the proper functioning of a democratic state ruled by law.

The paper is an attempt to analyse public hearing in terms of the impact of this form of participation on the legislative proceedings at the Senate stage. The main goal was achieved by presenting a number of detailed issues in this area, such as: analysing the adopted legal regulations, synthesizing the views of the doctrine of constitutional law, presenting the practice of application and indicating solutions that could contribute to the improvement of the quality of legislative procedures. The research was based on the study of the sources of law and the analysis of the available literature. In order to implement the assumed topic, methods appropriate for the legal and dogmatic analysis, focusing mainly on the exegesis of normative acts, were used. The lack of a current study spoke in favour of the need to undertake research in this area.

1 See J. Galster, D. Lis-Staranowicz, Konstytucja a suweren, "Państwo i Prawo" 2019, no. 6, p. 20; K.J. Kaleta, Bezpośrednia partycypacja obywateli w polityce konstytucyjnej (wyzwania i ograniczenia), "Państwo i Prawo" 2020, no. 5, pp. 4-5; P. Kędziora, Procedura przygotowania projektu ustawy. Postępowanie ustawodawcze na etapie sejmowym, [in:] Zarys metodyki pracy legislatora. Ustawy, akty wykonawcze, prawo miejscowe, ed. A. Malinowski, Warszawa 2009, p. 167; M. Bożek, M. Karpiuk, J. Kostrubiec, K. Walczuk, Zasady ustroju politycznego państwa, Poznań 2012, pp. 200-218.

2 W. Orłowski, O potrzebie optymalizacji procesu ustawodawczego w Polsce, "Studia Iuridica Lublinensia" 2014, vol. 22, p. 479; A. Kustra-Rogatka, Konstytucjonalizm a polityczność, "Krytyka Prawa. Niezależne Studia Nad Prawem” 2020, vol. 12(3), p. 56.

3 K. Zawiślak, Inspiracja ustawodawcza w polskim procesie legislacyjnym, "Przegląd Prawa Konstytucyjnego" 2017, no. 4, p. 48, 63.

4 L. Dubel, J. Kostrubiec, G. Ławnikowicz, Z. Markwart, Elementy nauki o państwie i polityce, Warszawa 2011, pp. 156-157. 


\section{THE ESSENCE OF PUBLIC HEARING}

Public hearing is an interesting form of social participation used in the legislative process, which supports the implementation of the idea of national sovereignty. ${ }^{5}$ The establishment of this institution is related to the development of democracy in Great Britain, the United States, Canada and Australia. ${ }^{6}$ It is common all over the world, both at the central and regional levels as well as internationally. ${ }^{7}$

As emphasized in the literature on the subject, the introduction of public hearing to the Polish legal order was to involve social, professional and individual groups in the process of shaping state policy and law-making, guarantee the activation of individuals in the public sphere, strengthen the sense of responsibility for the fate of the state and identification with the authorities decisions. ${ }^{8}$ Therefore, this institution is in line with the constitutional ideas concerning the democratic state ruled by law, the sovereignty of the nation, social dialogue, and the right to be informed about the activities of public authorities. ${ }^{9}$

The purpose of this instrument is to involve the public in law-making not only by familiarizing them with the proposed legislative solutions, but also by enabling interested external entities to take a position on a specific bill that is in the course of legislative work, in order to obtain and collect information and opinions ${ }^{10}$ on issues set out in the draft act. ${ }^{11}$ Presentation of various arguments is to lead to a clash of contradictory interests of the hearing participants and to working out an optimal

5 More broadly, see I. Wróblewska, Wystuchanie publiczne w Polsce. Analiza rozwiązań normatywnych na tle praktyki ich stosowania, "Przegląd Sejmowy" 2012, no. 3, p. 89 ff.; S. Patyra, Wystuchanie publiczne jako środek partycypacji społecznej w sejmowym postępowaniu ustawodawczym, [in:] Prawo naszych sąsiadów. Konstytucyjne podstawy budowania i rozwoju społeczeństwa obywatelskiego w Polsce i na Ukrainie, ed. W. Skrzydło, Rzeszów 2013, pp. 231-234; P. Dobrowolski, Dekada publicznego wystuchania w Polsce. Główne wnioski. Propozycje kierunku rozwoju, Warszawa 2018, p. 183.

6 G. Kuca, Wystuchanie publiczne, [in:] Wielki stownik parlamentarny, ed. J. Szymanek, Warszawa 2018, p. 1143.

7 More broadly, see M.M. Wiszowaty, Wystuchanie publiczne, [in:] Leksykon prawa konstytucyjnego. 100 podstawowych pojęć, ed. A. Szmyt, Warszawa 2016, pp. 478-480.

8 P. Kuczma, Model ogólnokrajowych konsultacji społecznych w Polsce, Torun 2018, p. 395.

9 Articles 2, 4, 20 and 61 of the Constitution of the Republic of Poland of 2 April 1997 (Journal of Laws 1997, no. 78, item 483, as amended). English translation of the Constitution at: www.sejm. gov.pl/prawo/konst/angielski/kon1.htm [access: 10.10.2021].

${ }_{10}$ In its jurisprudence, the Constitutional Tribunal indicated that the purpose of a public hearing is to read opinions that are not binding. See judgement of the Constitutional Tribunal of 3 November 2006, K 31/06, OTK-A 2006, no. 10, item 147.

11 See P. Uziębło, Demokracja partycypacyjna. Wprowadzenie, Gdańsk 2009, p. 54. 
solution. One should share the view that a hearing is a form of public debate which is a non-binding instrument of public participation. ${ }^{12}$

It is worth emphasizing that under the formalized procedure, public hearing is to be based mainly on the principle of openness. As a result, the law-making process is made public and corruption is limited. ${ }^{13}$ This institution should contribute to educating the society, whose representatives, in order to take part in the debate, must first get acquainted with the draft legal act. ${ }^{14}$

\section{THE PLACE OF PUBLIC HEARING IN THE SENATE LEGISLATIVE PROCEEDING}

Public hearing was introduced into the Polish legal system on the basis of the Act of 7 July 2005 on lobbying activities in the law-making process. ${ }^{15}$ Pursuant to this regulation, the indicated institution may be initiated in relation to a bill submitted to the Sejm, which in turn is made more precise by the provisions of its regulations. In the case of the Senate, public hearing was introduced under the statutory autonomy of this House of Parliament. ${ }^{16}$

The process of conducting a public hearing in the second chamber of parliament is regulated in particular by Article 80 (1b) and Article 80a of the Regulations of the Senate.$^{17}$ A resolution on its conduct is passed by Senate committee ${ }^{18}$ after the first reading of a bill being the subject of a Senate legislative initiative. ${ }^{19}$ There are no guidelines as to which bills should be heard, and there are no restrictions as to their content. It seems that they may be projects of significant social importance

${ }^{12}$ P. Uziębło, Instytucja wystuchania publicznego w sprawie projektów ustaw w Polsce (selected issues), "Gdańskie Studia Prawnicze” 2014, vol. 31, pp. 688-689.

13 J. Tracz-Dral, Instytucja wystuchania publicznego. Opracowania tematyczne OT-590, Warszawa 2010, p. 3.

${ }^{14}$ M. Borski, Wystuchanie publiczne - ważna, chociaż niedoceniana instytucja demokracji partycypacyjnej, "Roczniki Administracji i Prawa" 2016, no. 1, p. 32.

15 Journal of Laws 2017, item 248.

16 Resolution of the Senate of the Republic of Poland of 20 June 2013 on amendments to the Regulations of the Senate (M.P. 2013, item 558).

${ }^{17}$ Resolution of the Senate of the Republic of Poland of 23 November 1990 - Regulations of the Senate (consolidated text, Polish Monitor 2018, item 846), hereinafter: Regulations of the Senate.

18 While working on a bill, committee chairmen may commission an opinion and invite experts from circles and organizations interested in the subject of the committee's work to participate in its meetings, as well as other persons (Article 60 (6) of the Regulations of the Senate). Due to the lack of detailed provisions concerning the course of the public hearing, the deliberations of the committees are held according to the general rules specified in the Chamber's bylaws.

19 A public hearing is less important than public consultations, as their omission does not constitute grounds for challenging the enactment of the act. See judgement of the Constitutional Tribunal of 3 November 2006, K 31/06, OTK-A 2006, no. 10, item 147. 
due to the nature of the instrument. It should be emphasized that the hearing is an optional tool, so it is not carried out with regard to every draft bill being the subject of the Senate's work, but only when a motion for a hearing is submitted and the committee of the second chamber adopts a resolution in this regard.

The meeting connected with this institution is of a special nature as it cannot cover matters other than a public hearing. This should be assessed positively as it allows the committee to focus only on this item on the agenda. The resolution together with the information relating to the place of the public hearing are announced on the Senate's website at least 21 days before the hearing. ${ }^{20}$

The catalogue of entities authorized to participate in the hearing has been defined very broadly. This applies to both natural persons, legal persons and various types of social organizations. ${ }^{21}$ Anyone interested in Senate legislative work on a bill has the opportunity to participate and present their views during the hearing, after meeting certain requirements. ${ }^{22}$ The Senate regulations grant the right to participate in the hearing to those entities which notify the committees of such a wish at least 7 days before the hearing, in writing or to the e-mail address announced on the Senate's website. The latter possibility of nominating participants to take part in the hearing should be assessed favourably in terms of the speed of information transfer. The notification should include, i.a., basic data of the entity applying for participation in the hearing, as well as the interest that the applicant intends to protect in relation to a given regulation, or the legal solution that will be taken into account. ${ }^{23}$

The chairmen of the committee decide on the order and time of the speeches of the persons who participate in the public hearing. As time may be divided differently between participants, there may be allegations of unequal treatment. However, a hearing participant may appear several times, which may marginalize the above objection.

In the Senate, the chairman of the committee has the power to limit the number of people participating in a public hearing, which must be dictated by objective

${ }^{20}$ See Wystuchanie publiczne, www.senat.gov.pl/prace/konsultacje-i-wysluchania/wysluchanie -publiczne [access: 2.09.2021].

${ }^{21}$ It can be assumed that, for practical reasons, preference is given to collective entities that are able to contribute valuable and well-prepared information, i.e. expert circles, citizens' associations, etc. See M. Borski, Wystuchanie publiczne..., p. 32.

${ }^{22}$ It should be noted that the literature on the subject distinguishes between groups of eligible persons: professional lobbyists, unregistered lobbyists and entities that have reported interest in the work on the Senate bill pursuant to Article 80a of the Regulations of the Senate. See P. Kuczma, op. cit., p. 406; P. Uziębło, Instytucja wystuchania ..., pp. 693-694.

${ }^{23}$ Pursuant to the provisions of Article 63 (3) of the Regulations of the Senate, in a situation where professional lobbyists participate in a committee meeting, the rapporteur informs about the activities undertaken by these entities during the work of the committee, indicating the method of settlement expected by them and the position of the committee on this matter. 
circumstances applied uniformly to all interested parties in the event that the number of applications exceeds the number of available seats in the meeting room. Such circumstances may arise when the bill significantly raises social emotions. It should be emphasized that the term "objective criteria" is imprecise, it gives the chairman some area of discretion in this sphere, resulting in the possibility of blocking some willing to present their opinions. Therefore, it is important to choose an objective condition. This seems to be the use of the order of notifications. Information on the applied criterion and persons admitted to participate in the public hearing is announced on the Senate's website at least 3 days before the public hearing.

In particularly justified cases, the public hearing procedure allows for its postponement. The authorized person in this respect is the chairman of the committee meeting, who independently decides about the date, time and place of its resumption. It seems reasonable for him to consult committee members or participants in the public hearing on this matter. This would be really necessary because the latter are the actors who play the main role during the hearing. ${ }^{24}$ It is worth adding that the Senate Regulations do not provide for the possibility of cancelling a public hearing.

The committees are obliged to respond to the postulates and comments made during the public hearing, present the resulting conclusions and indicate, if necessary, the reasons for not taking them into account.$^{25}$ The positive assessment of this solution should be shared, as obliging the committee to take such a position requires a thorough analysis of the information obtained in terms of its usefulness and application in further stages of the legislative process. ${ }^{26}$ However, the regulations do not require the use of this information in further stages of the legislative procedure.

In principle, a public hearing seems to be a good means of enabling interested parties outside parliament to present their views on bills that are subject to legislative work. However, despite the previously indicated advantages, this institution does not enjoy special interest, as initially forecasted, and therefore it is not used often. This may be partly due to the fact that it is a new institution in the Polish legal order, which has no constitutional and statutory basis in the legislative procedure. Certainly, an important reason for this state of affairs is the way of adopting a resolution to hold a public hearing, where the majority of committee members decide, and not those interested in bills. So far, only two hearings have been held in the Senate. The first concerned the bill on petitions in $2013,{ }^{27}$ and the other one related to the bill amending the Act on the National Council of the Judiciary

24 P. Uziębło, Instytucja wystuchania..., p. 697.

${ }^{25}$ Information on this matter is published on the Senate's website within 30 days from the date of the end of the public hearing.

${ }^{26}$ P. Kuczma, op. cit., p. 432; M. Borski, Wystuchanie publiczne ..., p. 38.

${ }^{27}$ Senate's print for the $8^{\text {th }}$ term no. 285. 
in $2020 .{ }^{28}$ The possibilities offered by the hearing are evidenced by the fact that some of the comments submitted by the participants in the hearings were taken into account by the Senate committees. ${ }^{29}$

\section{DEVELOPMENT PROSPECTS OF THE INSTITUTION}

When assessing the above regulations regarding public hearing, it should be emphasized that it is an easy-to-implement institution and does not involve high financial outlays. The unquestionable advantage of this instrument is that it allows for quick collection of postulates and comments on bills presented by interested entities..$^{30}$ Due to the variety of views presented, it allows decision-makers to confront the different interests of the participants in the public hearing.

Due to the very rare use of the hearing so far, it is a "purely theoretical" institution with untapped potential. Therefore, it seems that without changing certain regulations, and especially the practice, it will not improve.

It would be worth considering changes in the organization of the work of Senate committees, as sometimes there is not enough time to properly carry out analyses on bills. It happens that the rush accompanying the works also results in the lack of an honest discussion on the proposed legislative changes. ${ }^{31}$ Therefore, it is extremely important to adopt a resolution to hold a public hearing in advance, and to organize an appropriate promotion of this event in order to involve, in particular, social participants. It would be worthwhile to send invitations to individuals and social groups who can demonstrate specialist knowledge.

At the same time, the current political conditions and the level of public participation in public life should be taken into account. Currently, we are dealing with a crisis that results from the lack of community thinking, the growth and domination of the role of political parties that do not communicate properly with the society, so

${ }^{28} 10^{\text {th }}$ term Senate print no. 50. At the beginning of the current parliamentary term, when it turned out that the two chambers had different majorities, it seemed that the Senate would become an "open chamber" and would be more oriented towards using forms of public participation. However, it ended with announcements.

${ }^{29}$ For example, in the case of this first public hearing, one of the provisions of the bill provided for the exclusion of entities that professionally engage in lobbying activities from the right to petition. After the comment submitted by the Stefan Batory Foundation, who stated that such a norm could be considered unconstitutional, it was removed.

${ }^{30}$ More broadly, see A. Gross, Wystuchanie publiczne jako szczególna forma aktywności obywatelskiej w kontekście procesów partycypacyjnych, "Przegląd Prawa Publicznego" 2017, no. 11, p. 99.

31 R. Orłowski, Legal Consequences of Violation of Time Limits in Legislative Proceedings, "Studia Iuridica Lublinensia" 2020, vol. 29(5), p. 258. 
the democratic deficit is growing. ${ }^{32}$ The doctrine emphasizes that there is a tendency to marginalize the participation of social organizations in the law-making process. ${ }^{33}$ It is necessary to change the mentality of the participants of the legislative process in order to make them aware that the legal system being created is a common good, both for public authorities and citizens. It is also necessary to create certain rules of cooperation of all entities involved in this process and then to abide by these rules. ${ }^{34}$ Hopes for streamlining the procedure can be associated with the slowly progressing processes of Europeanization indicating the assumptions of citizens' cooperation in the process of making public decisions. ${ }^{35}$

A public hearing is used incidentally, which results mainly from the freedom of its use and the pace of the course of the legislative procedure. The proposal to introduce obligatory public hearings should be considered, primarily in matters related to the principles of a democratic state of law and subsidiarity. ${ }^{36}$ It would certainly make it easier for citizens and social entities to engage in public life, and would also enable a better understanding of the functions and methods of operation of state bodies. They could actively participate in law-making more often, thus becoming more socially aware and responsible for the good of the state. In this way, civil society would be built and developed. On the other hand, the comments and postulates concerning the bills presented in the public hearing may enable the members of the commission to learn about social needs and constitute a source of inspiration for them.

The current regulation of public hearing is inconsistent and incomplete both in the process of adopting laws and issuing regulations. Therefore, it is necessary to consider the creation of a law which will be comprehensively devoted to this insti-

${ }^{32} \mathrm{~K}$. Piech, Instytucje demokracji bezpośredniej w polskim porządku prawnym, "Przegląd Prawniczy Uniwersytetu Warszawskiego" 2015, no. 1, p. 134.

${ }_{33}$ M. Borski, O potrzebie reformy polskiego systemu stanowienia prawa, "Przegląd Prawa Konstytucyjnego" 2016, no. 4, p. 241.

${ }^{34}$ Parliamentary bodies and decision-makers can draw positive models for the effective use of forms of social participation occurring in local government.

${ }^{35}$ In the law of the European Union, there are many norms regulating the general principle of direct participation of citizens in the process of making public decisions. In particular, Article 1 sentence 2 of the Treaty on European Union (Journal of Laws 2004, no. 90, item 864/30). According to its provisions, this act marks a new stage in the process of creating an ever closer union among the peoples of Europe, in which decisions are taken with the highest possible respect for the principle of openness and as closely as possible to citizens. In turn, Article 8a (3) of the Treaty of Lisbon indicates that every citizen has the right to participate in the democratic life of the Union, and decisions are to be taken in the most open and citizen-like manner (See Treaty of Lisbon amending the Treaty on European Union and the Treaty establishing the European Community, drawn up in Lisbon on 13 December 2007, Journal of Laws 2009, no. 203, item 1569). Moreover, the content of Article 8b (2) of that act obliges the institutions of the Union to maintain an open, transparent and regular dialogue with representative associations and civil society.

${ }^{36}$ More broadly, see M. Borski, Wystuchanie publiczne..., pp. 41-42. 
tution. ${ }^{37}$ Undoubtedly, precise regulations will increase the clarity of law-making procedures in the scope related to this instrument. At the same time, as experience pertaining to the legislative process has shown, one should consider introducing the possibility of organizing a public hearing by the Senate after the completion of the work on the bill in the Sejm. It would be justified to conduct it at the stage of commission works related to the preparation of the Senate's position on the act passed by the first chamber of parliament. ${ }^{38}$ The Senate could therefore conduct a public hearing in a situation where important bills were not properly consulted at an earlier stage in the proceedings.

It is worth bearing in mind that currently citizens are less and less interested in traditional forms of social participation. As shown by the experiences of mature democracies, decision-makers more and more often use the tools of new technologies to contact citizens. ${ }^{39}$ This allows you to reach a wide audience and, consequently, to develop the entire system in accordance with the principles of a democratic state ruled by law. ${ }^{40}$ Therefore, it would be worth enabling remote participation in a public hearing, which is possible thanks to the rapid development of distance communication tools. Firstly, it would allow the participation in this instrument by persons who would not decide to participate in it due to the considerable distance from their place of residence or stay from the seat of the Senate. Secondly, non-mobile people could participate in public hearing. Thirdly, it would solve the problem of size limitations in the room where committee meetings can be held. As a consequence, this solution would stimulate the activation of the society and would make public hearing a universal one.

\section{CONCLUSIONS}

If the Senate is to be a place of authoritative social discussion and a creator of state policy, it is necessary to strive for changes to the regulations and the practice of their application in the above-mentioned scope. It should ensure the development of rational legislation, so that the legislative procedure, including the use of public

${ }^{37}$ See G. Makowski, Instytucja wystuchania publicznego w Polsce jako mechanizm partycypacji obywateli w procesie stanowienia prawa, [in:] Organizacje pozarzadowe, dialog obywatelski, polityka państwa, ed. M. Rymsza, Warszawa 2007, pp. 186-187.

${ }_{38}$ M. Borski, Wystuchanie publiczne..., p. 41.

${ }^{39}$ M. Marczewska-Rytko, Idea demokracji bezpośredniej od okresu antycznego do czasów Internetu i globalizacji, [in:] Demokracja bezpośrednia. Wymiar globalny i lokalny, eds. M. Marczewska-Rytko, A.K. Piasecki, Lublin 2010, pp. 13 ff.

${ }^{40}$ See M. Jabłoński, Rola i znaczenie instytucji demokracji bezpośredniej we wspótczesnym państwie, [in:] Instytucje demokracji bezpośredniej w praktyce, eds. O. Hałub, M. Jabłoński, M. Radajewski, Wrocław 2016, p. 23. 
hearing, is carried out in accordance with its optimization, as well as the practicality of the introduced provisions. ${ }^{41}$ In a democratic state ruled by law, procedures are undoubtedly the basis. They create an appropriate framework within which established actors take action to legislate. It is particularly important to eliminate the currently existing instability and excess of regulations that reduce the transparency of the legal system. The Senate should strive to actively promote the institutions of participation and be their recipient who thoroughly analyses the submitted postulates. It should be borne in mind that legislative proceedings must be viewed as a whole. Therefore, it is not possible to improve only its selected elements. Taking into account the forms of social participation, including public hearings, it is necessary to create a uniform system of comprehensively regulated instruments that complement each other.

\section{REFERENCES}

\section{Literature}

Biernat T., On the Lawmaking Policy, Discretion and Importance of the Rule of Law Standards, "Studia Iuridica Lublinensia" 2020, vol. 29(3), DOI: http://dx.doi.org/10.17951/sil.2020.29.3.67-85.

Borski M., O potrzebie reformy polskiego systemu stanowienia prawa, "Przegląd Prawa Konstytucyjnego" 2016, no. 4.

Borski M., Wystuchanie publiczne - ważna, chociaż niedoceniana instytucja demokracji partycypacyjnej, "Roczniki Administracji i Prawa" 2016, no. 1.

Bożek M., Karpiuk M., Kostrubiec J., Walczuk K., Zasady ustroju politycznego państwa, Poznań 2012.

Dobrowolski P., Dekada publicznego wystuchania w Polsce. Główne wnioski. Propozycje kierunku rozwoju, Warszawa 2018.

Dubel L., Kostrubiec J., Ławnikowicz Ł., Markwart Z., Elementy nauki o państwie i polityce, Warszawa 2011.

Galster J., Lis-Staranowicz D., Konstytucja a suweren, "Państwo i Prawo" 2019, no. 6.

Gross A., Wystuchanie publiczne jako szczególna forma aktywności obywatelskiej w kontekście procesów partycypacyjnych, "Przegląd Prawa Publicznego" 2017, no. 11.

Jabłoński M., Rola i znaczenie instytucji demokracji bezpośredniej we współczesnym państwie, [in:] Instytucje demokracji bezpośredniej w praktyce, eds. O. Hałub, M. Jabłoński, M. Radajewski, Wrocław 2016.

Kaleta K.J., Bezpośrednia partycypacja obywateli w polityce konstytucyjnej (wyzwania i ograniczenia), "Państwo i Prawo" 2020, no. 5.

Kędziora P., Procedura przygotowania projektu ustawy. Postępowanie ustawodawcze na etapie sejmowym, [in:] Zarys metodyki pracy legislatora. Ustawy, akty wykonawcze, prawo miejscowe, ed. A. Malinowski, Warszawa 2009.

Kuca G., Wystuchanie publiczne, [in:] Wielki stownik parlamentarny, ed. J. Szymanek, Warszawa 2018. Kuczma P., Model ogólnokrajowych konsultacji społecznych w Polsce, Toruń 2018.

${ }^{41}$ See T. Biernat, On the Lawmaking Policy, Discretion and Importance of the Rule of Law Standards, "Studia Iuridica Lublinensia" 2020, vol. 29(3), p. 69. 
Kustra-Rogatka A., Konstytucjonalizm a polityczność, "Krytyka Prawa. Niezależne Studia Nad Prawem" 2020, vol. 12(3), DOI: https://doi.org/10.7206/kp.2080-1084.395.

Makowski G., Instytucja wystuchania publicznego w Polsce jako mechanizm partycypacji obywateli w procesie stanowienia prawa, [in:] Organizacje pozarzadowe, dialog obywatelski, polityka państwa, ed. M. Rymsza, Warszawa 2007.

Marczewska-Rytko M., Idea demokracji bezpośredniej od okresu antycznego do czasów Internetu i globalizacji, [in:] Demokracja bezpośrednia. Wymiar globalny i lokalny, eds. M. Marczewska-Rytko, A.K. Piasecki, Lublin 2010.

Orłowski R., Legal Consequences of Violation of Time Limits in Legislative Proceedings, "Studia Iuridica Lublinensia" 2020, vol. 29(5), DOI: http://dx.doi.org/10.17951/sil.2020.29.5.249-264.

Orłowski W., O potrzebie optymalizacji procesu ustawodawczego w Polsce, "Studia Iuridica Lublinensia" 2014, vol. 22, DOI: http://dx.doi.org/10.17951/sil.2014.22.0.479.

Patyra S., Wystuchanie publiczne jako środek partycypacji społecznej w sejmowym postępowaniu ustawodawczym, [in:] Prawo naszych sąsiadów. Konstytucyjne podstawy budowania i rozwoju społeczeństwa obywatelskiego w Polsce i na Ukrainie, ed. W. Skrzydło, Rzeszów 2013.

Piech K., Instytucje demokracji bezpośredniej w polskim porządku prawnym, "Przegląd Prawniczy Uniwersytetu Warszawskiego" 2015, no. 1.

Tracz-Dral J., Instytucja wystuchania publicznego. Opracowania tematyczne OT-590, Warszawa 2010.

Uziębło P., Demokracja partycypacyjna. Wprowadzenie, Gdańsk 2009.

Uziębło P., Instytucja wystuchania publicznego w sprawie projektów ustaw w Polsce (selected issues), "Gdańskie Studia Prawnicze" 2014, vol. 31.

Wiszowaty M.M., Wystuchanie publiczne, [in:] Leksykon prawa konstytucyjnego. 100 podstawowych pojęć, ed. A. Szmyt, Warszawa 2016.

Wróblewska I., Wystuchanie publiczne w Polsce. Analiza rozwiązań normatywnych na tle praktyki ich stosowania, "Przegląd Sejmowy" 2012, no. 3.

Zawiślak K., Inspiracja ustawodawcza w polskim procesie legislacyjnym, "Przegląd Prawa Konstytucyjnego" 2017, no. 4.

\section{Online sources}

Wystuchanie publiczne, www.senat.gov.pl/prace/konsultacje-i-wysluchania/wysluchanie-publiczne [access: 2.09.2021].

\section{Legal acts}

Act of 7 July 2005 on lobbying activities in the law-making process (Journal of Laws 2017, item 248).

Constitution of the Republic of Poland of 2 April 1997 (Journal of Laws 1997, no. 78, item 483, as amended).

Resolution of the Senate of the Republic of Poland of 23 November 1990 - Regulations of the Senate (consolidated text, Polish Monitor 2018, item 846).

Resolution of the Senate of the Republic of Poland of 20 June 2013 on amendments to the Regulations of the Senate (M.P. 2013, item 558).

Treaty on European Union (Journal of Laws 2004, no. 90, item 864/30).

Treaty of Lisbon amending the Treaty on European Union and the Treaty establishing the European Community, drawn up in Lisbon on 13 December 2007 (Journal of Laws 2009, no. 203, item 1569).

\section{Case law}

Judgement of the Constitutional Tribunal of 3 November 2006, K 31/06, OTK-A 2006, no. 10, item 147. 
Pobrane z czasopisma Studia Iuridica Lublinensia http://studiaiuridica.umes.pl Data: 26/04/2023 04:34:18

\begin{abstract}
ABSTRAKT
W niniejszym artykule przedstawiono zagadnienia odnoszące się do wysłuchania publicznego jako społecznego instrumentu wpływającego na procedurę ustawodawczą w Senacie. Instytucja ta wpisuje się w założenia konstytucyjne odnoszące się do zasad demokratycznego państwa prawnego, suwerenności narodu, dialogu społecznego oraz prawa do informacji o działalności organów władzy publicznej. Rozważania zaczynają się od analizy regulacji prawnych normujących ten instrument. Praktyka pokazuje, że niestety nie wykorzystuje się właściwie potencjału wysłuchania publicznego, gdyż to narzędzie partycypacji społecznej jest niezwykle rzadko stosowane. W dalszej części artykułu zostały opisane elementy procesu stanowienia prawa wymagające zmian, które mogłyby przyczynić się do poprawy jego efektywności. Szczególnie modyfikacje powinny być realizowane w sferze instytucjonalnej, w ramach stworzenia transparentnych zasad współpracy uczestników procesu tworzenia prawa.
\end{abstract}

Słowa kluczowe: wysłuchanie publiczne; Senat; procedura ustawodawcza; partycypacja społeczna; Polska 